\title{
Ketimpangan pendapatan dan faktor-faktor yang mempengaruhi pada masa sebelum dan pada saat pandemi COVID-19 di Indonesia
}

\author{
Fidelis Dwi Putra Santoso*, Imam Mukhlis \\ Universitas Negeri Malang, Jl. Semarang No. 5 Malang, Jawa Timur, Indonesia \\ *Penulis korespondensi, Surel: fidelis.dwiputras@gmail.com
}

Paper received: 2-2-2021; revised: 20-2-2021; accepted: 27-2-2021

\begin{abstract}
Abstrak
Penelitian ini bertujuan untuk menganalisis pengaruh desentralisasi fiskal (DAU, DAK, dan DBH), foreign direct investment, dan tenaga kerja terhadap ketimpangan pendapatan di Indonesia pada masa sebelum pandemi COVID-19 serta perbandingan kondisi pada saat pandemi COVID-19. Analisis data yang dilakukan adalah dengan menggunakan analisis regresi data panel pada data sebelum pandemi dan analisis deskriptif pada data selama pandemi COVID-19. Data penelitian diperoleh dari publikasi yang disediakan oleh Direktorat Jenderal Perimbangan Keuangan Kementerian Keuangan (DJPK Kemenkeu), Badan Koordinasi Penanaman Modal (BKPM) dan Badan Pusat Statistik (BPS). Data yang digunakan sejak tahun 2010 hingga tahun 2020. Hasil penelitian menunjukkan bahwa variabel Dana Alokasi Khusus (DAK) berpengaruh signifikan terhadap ketimpangan pendapatan di Indonesia. Sedangkan, variabel Dana Alokasi Umum, Dana Bagi Hasil, Foreign Direct Investment, dan Tenaga Kerja tidak berpengaruh signifikan terhadap ketimpangan pendapatan di Indonesia. Berdasarkan analisis deskriptif pada data selama pandemi COVID-19 didapatkan hasil bahwa kondisi ketimpangan pendapatan, desentralisasi fiskal (DAU, DAK, dan DBH), FDI, dan tenaga kerja di Indonesia pada masa pandemi COVID-19 mengalami perubahan dimana seluruh aspek mengalami penurunan. Hal ini disebabkan pada kondisi pandemi yang membuat pemerintah melakukan kebijakan lockdown atau yang di Indonesia dikenal dengan istilah PSBB.
\end{abstract}

Kata kunci: dana perimbangan; desentralisasi; FDI; ketimpangan; TPAK

\section{Pendahuluan}

Tujuan setiap negara di dunia dalam proses pemerintahan mereka adalah kesejahteraan masyarakatnya. Untuk itu, pemerintah melakukan berbagai kebijakan agar memastikan proses pembangunan di negaranya dapat berjalan sesuai rencana serta dapat berdampak signifikan bagi kesejahteraan warganya. Pembangunan ekonomi pada umumnya dapat didefinisikan sebagai proses yang menyebabkan kenaikan pendapatan riil per kapita penduduk suatu negara dalam jangka panjang yang disertai oleh perbaikan sistem kelembagaan (institutional) (Arsyad, 2016). Ketika menilai apakah perekonomian sedang berada pada kondisi yang baik atau tidak, hal yang biasa dilakukan adalah dengan melihat pendapatan total tiap orang yang diperoleh dari kegiatan ekonomi (Mankiw, 2018). Sehingga, pendapatan per kapita penduduk suatu negara bisa dikatakan sebagai salah satu indikator suatu negara dalam melihat apakah proses pembangunan ekonomi di negara tersebut sudah berhasil atau tidak. Berdasarkan data yang dirilis oleh BPS bisa dilihat perkembangan PDRB per kapita yang dialami oleh Indonesia. Pada tahun 2015, PDRB per kapita Indonesia adalah sebesar Rp 35.161.890, kemudian terus naik hingga data terakhir pada tahun 2018 mencapai Rp 39.338.590 (BPS, 2019). Hal ini menunjukkan jika proses pembangunan yang dilakukan oleh Indonesia sudah mulai menunjukkan hasil yang positif, dilihat dari salah satu indikator yang naiknya pendapatan per kapita penduduk. 
Namun, pendapatan per kapita penduduk saja belum cukup bila dijadikan satu - satunya patokan dalam melihat kinerja pembangunan suatu negara. Meningkatnya pendapatan per kapita penduduk belum tentu menggambarkan pembangunan ekonomi suatu negara. Oleh sebab itu, pembangunan haruslah dipandang sebagai proses multidimensi yang melibatkan berbagai perubahan mendasar dalam struktur sosial, sikap masyarakat, dan lembaga nasional; serta percepatan pertumbuhan, pengurangan ketimpangan, dan penanggulangan kemiskinan (Todaro \& Smith, 2011).

Perhatian khusus mengenai ketimpangan pendapatan bisa dilihat dari berbagai macam penelitian serta teori dari berbagai orang. Salah satunya adalah dari teori yang dikemukakan oleh Simon Kuznet mengenai adanya hubungan antara ketimpangan dengan pertumbuhan perekonomian. Simon Kuznet mengemukakan bahwa pada awal tahapan pertumbuhan perekonomian, distribusi pendapatan akan cenderung memburuk, hanya pada tahapan berikutnyalah perekonomian akan membaik (Todaro \& Smith, 2011). Selain itu, jika pembangunan ekonomi lebih difokuskan untuk mencapai tingkat pertumbuhan ekonomi yang tinggi, maka semakin besar kemungkinan terjadi ketimpangan pendapatan (Kuncoro, 2003).

Ketimpangan pendapatan juga menjadi permasalahan ekonomi yang dihadapi oleh Indonesia. Hal tersebut bisa dilihat pada data yang dirilis oleh Badan Pusat Statistik. Berdasarkan data mengenai tingkat ketimpangan yang ada di Indonesia periode 2015 -2019 yang dihitung dari nilai koefisien Gini Index dapat dilihat jika tingkat ketimpangan di Indonesia mengalami perkembangan yang positif. Hal ini bisa dilihat pada nilai ketimpangan pendapatan secara agregat dimana nilainya semakin menurun tiap tahunnya. Pada tahun 2015, koefisien Gini Index Indonesia adalah sebesar 0.402, kemudian terus menurun hingga pada tahun 2019 mencapai angka 0.38 (BPS, 2019). Namun, jika data dipecah menurut provinsi maka akan menghasilkan data yang cukup menarik. Beberapa daerah mengalami fluktuasi terkait dengan nilai koefisien Gini Index mereka. Contohnya pada Provinsi DKI Jakarta yang merupakan ibukota sekaligus daerah urban dengan pembangunan yang sangat cepat. Nilai koefisien Gini Index mereka pada tahun 2015 adalah sebesar 0.421, kemudian sempat naik turun hingga pada tahun 2019 mencapai angka 0.391. Daerah lain yang mengalami hal serupa adalah Provinsi Lampung, dimana nilai koefisien Gini Index mereka pada tahun 2015 adalah sebesar 0.275, kemudian sempat naik di tahun 2016 lalu mengalami penurunan di tahun 2017 dan 2018 dan pada tahun 2019 naik lagi dengan angka terakhir sebesar 0.331. Dengan meningkatnya tingkat pertumbuhan ekonomi tiap tahun disertai dengan tingkat ketimpangan yang masih fluktuatif di berbagai daerah menunjukkan jika kebijakan pembangunan ekonomi di Indonesia, khususnya pada level provinsi masih belum maksimal dalam menurunkan tingkat ketimpangan pendapatan di daerah mereka.

Pemerintah Indonesia sendiri sudah melakukan beberapa cara berkaitan dengan proses pembangunan ekonomi di daerah. Salah satunya adalah pelaksanaan desentralisasi fiskal. Desentralisasi fiskal mulai dilaksanakan sejak tahun 2001 di Indonesia, dimana pemerintahan yang sebelumnya bersifat sentralistik berubah menjadi desentralistik (Putri, 2019). Hal ini artinya setiap daerah otonom dapat mengelola daerahnya sendiri, baik dari sisi keuangan maupun kebijakan. Dengan adanya desentralisasi fiskal diharapkan mampu memeratakan pembangunan serta mengembangkan wilayah masing - masing sesuai potensi yang ada.

Menurut Adelman dan Morris (1973) (Arsyad, 2016) ada delapan penyebab ketidakmerataan distribusi pendapatan di negara sedang berkembang, yakni: (1) pertumbuhan 
pendudukyang tinggi memicu penurunan pendapatan per kapita; (2) inflasi di mana pendapatan atas uang bertambah namun tidak diikuti oleh produksi barang; (3) ketidakmerataan pembangunan antar daerah; (4) investasi yang padat modal lebih besar dari investasi padat karya; (5) mobilitas sosial rendah; (6) substitusi impor; (7) nilai tukar yang memburuk bagi negara sedang berkembang dalam perdagangan dengan negara maju, sebagai akibat adanya ketidakstabilan permintaan terhadap barang ekspor negara sedang berkembang; serta (8) industri kerajinan rakyat yang hancur.

Investasi diartikan sebagai pengeluaran atau pembelanjaan penanaman modal dan perlengkapan - perlengkapan produksi untuk menambah kemampuan memproduksi barang dan jasa yang tersedia dalam perekonomian, sehingga investasi dapat membantu proses pertumbuhan ekonomi (Sukirno, 2006) Sehingga, investasi ini sangat penting dalam proses pembangunan ekonomi. Peran investasi mendorong atau memicu kegiatan ekonomi di suatu daerah. Adanya modal baru yang besar mampu membuka lapangan pekerjaan yang baru sehingga masyarakat yang berada pada tingkat kemiskinan mampu memiliki pekerjaan yang layak sehingga berdampak pada pengurangan tingkat ketimpangan pendapatan. Namun, ketika pertumbuhan ekonomi yang tinggi karena disebabkan karena besarnya angka investasi, khususnya investasi asing (FDI) biasanya terjadi semacam trade-off antara pertumbuhan ekonomi dan ketimpangan pendapatan di daerah tersebut. Hal ini disebabkan oleh ketidakmampuan negara penerima modal asing (FDI) dalam memanfaatkannya; negara tuan rumah tidak dapat menyerap transfer teknologi yang dibawa oleh FDI dan tidak dapat menyediakan lapangan pekerjaan dari aktivitas FDI tersebut (Fazaalloh, 2019).

Tenaga kerja bisa menjadi salah satu faktor lain dalam hal ketimpangan pendapatan. Seseorang yang memiliki pekerjaan tentunya akan lebih mampu menghasilkan pendapatan yang lebih besar daripada seorang pengangguran. Sehingga semakin besar tenaga kerja yang bekerja pada sebuah perekonomian akan menyebabkan kesejahteraan masyarakatnya. Setidaknya dengan meningkatnya tenaga kerja maka akan menyebabkan hasil dari ketimpangan menurun. Penelitian ini bertujuan untuk menganalisis pengaruh desentralisasi fiskal, Foreign Direct Investment (FDI), dan tenaga kerja terhadap ketimpangan pendapatan di Indonesia.

Ketimpangan pendapatan merupakan distribusi yang tidak proporsional dari pendapatan nasional total di antara berbagai rumah tangga dalam negara (Todaro \& Smith, 2011). Menurut Kuncoro (2003) ketimpangan mengacu pada standar hidup relatif dari seluruh masyarakat. Berdasarkan beberapa pengertian mengenai ketimpangan pendapatan dapat dilihat jika ketimpangan pendapatan menunjukkan sebuah perbedaan yang besar antara masyarakat yang memiliki pendapatan tinggi (kaya) dan masyarakat yang memiliki pendapatan rendah (miskin). Hal ini juga menunjukkan standar hidup yang ada di masyarakat. Semakin tinggi pendapatan segelintir orang maka ketimpangan pendapatan akan semakin besar.

Secara umum, desentralisasi dapat diartikan sebagai pelimpahan wewenang dari pemerintah pusat ke level pemerintahan yang ada di bawahnya (Khusaini, 2006). Di Indonesia, pengertian desentralisasi fiskal telah diatur dalam Undang-Undang No. 33 Tahun 2004 yang menyatakan bahwa desentralisasi adalah penyerahan wewenang pemerintahan oleh pemerintah kepada daerah otonom untuk mengatur dan mengurus urusan pemerintahan dalam sistem Negara Kesatuan Republik Indonesia.

Berdasarkan Undang-Undang No. 33 Tahun 2004, Dana Alokasi Umum (DAU) adalah dana yang bersumber dari pendapatan APBN yang dialokasikan dengan tujuan pemerataan 
kemampuan keuangan antar-daerah untuk mendanai kebutuhan daerah dalam rangka pelaksanaan desentralisasi. Kebutuhan DAU tiap daerah berbeda-beda. Di Indonesia, penentuan kebutuhan DAU ditentukan melalui fiscal gap, dimana daerah yang mempunyai kemampuan keuangan lebih besar akan mendapatkan DAU yang relatif kecil, sedangkan daerah yang mengalami kesulitan secara finansial akan mendapatkan DAU yang lebih besar. Dana Alokasi Khusus (DAK) adalah dana yang berasal dari APBN, yang dialokasikan kepada daerah untuk membantu pembiayaan khusus (Khusaini, 2006). Menurut UU No. 25 tahun 1999 yang digantikan dengan UU No. 33 tahun 2004, yang dimaksud kebutuhan khusus adalah: (1) kebutuhan yang tidak dapat diperkirakan dengan menggunakan Dana Alokasi Umum; serta (2) kebutuhan yang merupakan komitmen atau prioritas nasional. Dana bagi Hasil adalah dana yang bersumber dari pendapatan APBN yang dialokasikan kepada Daerah berdasarkan angka persentase untuk mendanai kebutuhan Daerah dalam rangka pelaksanaan Desentralisasi. Untuk menambah pendapatan daerah dalam rangka pembiayaan pelaksanaan fungsi yang menjadi kewenangannya dilakukan dengan pola bagi hasil penerimaan pajak dan sumber daya alam antara pusat dan daerah (Khusaini, 2006).

Musgrave (1959) dan Oates (1972) membangun teori fiscal federalism yang menekankan pentingnya revenue dan expenditure assignment antar level pemerintahan dengan tujuan meningkatkan kesejahteraan masyarakat. Secara teoritik, dengan lebih dekat dengan masyarakatnya (their consistuent), seharusnya pemerintah daerah akan berperilaku berbeda ketika pemerintah pusat menyerahkan berbagai kepada pemerintah daerah, yaitu semakin berusaha meningkatkan kesejahteraan masyarakat lokal. Implikasi dari adanya desentralisasi fiskal adalah peningkatan pertumbuhan ekonomi lokal serta kesejahteraan masyarakatnya, karena pemerintah lebih tahu kondisi serta kebutuhan masyarakat yang ada dibawahnya. Lindahman \& Thurmaier (2002) meneliti tentang dampak desentralisasi fiskal terhadap kesejahteraan masyarakat yang diukur dari pencapaian masyarakat dalam memenuhi kebutuhan dasar, yaitu pendidikan dan kesehatan. Hasil kajian membuktikan jika desentralisasi fiskal berpengaruh positif terhadap kesejahteraan masyarakat. Hal ini memenuhi argumentasi sebelumnya jika pemerintah daerah lebih mengetahui kebutuhan serta kepentingan masyarakatnya.

Investasi terdiri dari barang-barang yang dibeli untuk penggunaan masa depan (Mankiw, 2006). Kaidah umum investasi adalah bahwa investasi perekonomian tidak mencakup pembelian yang hanya merealokasikan aset-aset yang ada di antara individu-individu yang berbeda, melainkan menciptakan modal baru (Mankiw, 2006). Menurut Krugman (1999), investasi asing langsung adalah arus modal internasional dimana perusahaan dari suatu negara mendirikan atau memperluas perusahaannya di negara lain. Menurut Salvatore (1997), investasi asing langsung meliputi investasi ke dalam aset-aset secara nyata, misalnya seperti pembangunan pabrik-pabrik, pengadaan berbagai macam barang modal, pembelian tanah untuk keperluan produksi, pembelanjaan berbagai peralatan inventaris dan sebagainya.

Beberapa teori berusaha menjelaskan pengaruh dari adanya penanaman modal asing bagi negara tuan rumah. Teori modernisasi di satu sisi dan teori ketergantungan dan sistem dunia di sisi lain adalah upaya pertama untuk menyelidiki hubungan antara penetrasi modal asing dan ketidaksetaraan pendapatan di negara tuan rumah (Mihaylova, 2015). Teori dependensia/ketergantungan pada awalnya dicetuskan oleh Paul Baran, yang membahas tentang keterbelakangan ekonomi yang dialami oleh negara dunia ketiga. Paul Baran melihat bahwa investasi perusahaan multinasional dari negara maju yang dilakukan di negara miskin 
akan meningkatkan pendapatan nasional negara miskin tersebut, namun peningkatan pendapatan ini tidak dapat dinikmati oleh sebagian besar masyarakat karena kepincangan dalam distribusi pendapatan (Kuncoro, 2003). Keuntungan semata-mata hanya hasil eksploitasi sumber daya yang ada, sehingga pendapatan yang masuk hanya kepada pengusaha asing serta segelintir orang yang ada di dalam negeri saja. Investasi asing memungkinkan bagi negara maju untuk mengeruk sebagian besar potensi ekonomi yang ada di negara miskin. Hasil bagi yang diberikan investor asing kepada negara tempat investasi berada (host country) jauh lebih rendah dibandingkan dengan tingkat keuntungan yang disalurkan kembali ke negara asal (home country) (Kuncoro, 2003).

Tenaga kerja merupakan salah satu aspek penting dalam pembangunan. Beberapa indikator untuk mengukur kondisi tenaga kerja di Indonesia salah satunya adalah Tingkat Partisipasi Angkatan Kerja (TPAK). Menurut Badan Pusat Statistik (BPS) (2019), TPAK merupakan persentase penduduk usia 15 tahun keatas yang merupakan angkatan kerja. Indikator ini mengindikasikan besarnya persentase penduduk usia kerja yang aktif secara ekonomi. Semakin besar TPAK maka menunjukkan penawaran tenaga kerja (labour supply) yang semakin besar tersedia dalam perekonomian. Menurut David Ricardo, pertumbuhan penduduk (tenaga kerja) akan menurunkan produk marginal (marginal product) yang kemudian kita kenal dengan istilah hukum kenaikan hasil yang semakin berkurang. Selama tenaga kerja yang dipekerjakan pada tanah tersebut bisa menerima tingkat upah diatas tingkat upah alamiah, jumlah penduduk (tenaga kerja) akan terus bertambah, sehingga menyebabkan semakin menurunnya produk marginal dan akhirnya akan menurunkan tingkat upah (Arsyad, 2016).

Berbagai penelitian telah dilakukan untuk menganalisis pengaruh desentralisasi fiskal, foreign direct investment, dan tenaga kerja terhadap ketimpangan pendapatan. Refqi \& Hidayat (2019) dalam studi mereka tentang pengaruh desentralisasi fiskal terhadap ketimpangan pendapatan di Indonesia menyimpulkan bahwa kebijakan alokasi Dana Alokasi Umum (DAU) berpengaruh signifikan dalam menurunkan tingkat ketimpangan wilayah di tiap provinsi di Indonesia. Sidik et. al. (2020) dalam studinya menyimpulkan jika alokasi Dana Alokasi Umum (DAU) berpengaruh positif dan signifikan terhadap ketimpangan pendapatan, alokasi Dana Alokasi Khusus (DAK) berpengaruh negatif dan signifikan terhadap ketimpangan pendapatan. Sedangkan, alokasi DBH tidak berpengaruh signifikan terhadap ketimpangan pendapatan.

Prawoto \& Cahyani (2020) dalam studinya menyimpulkan jika foreign direct investment tidak berpengaruh signifikan terhadap ketimpangan pendapatan di Pulau Jawa. Refqi \& Hidayat (2019) mendapatkan hasil yang serupa dimana foreign direct investment tidak berpengaruh signifikan terhadap ketimpangan. Sementara itu, Suryahani et. al. (2018) dalam studinya mendapatkan hasil yang berbeda, dimana foreign direct invetsment berpengaruh positif dan signifikan terhadap ketimpangan pendapatan. Cho \& Ramirez (2016) dalam studinya menyimpulkan jika foreign direct investment cenderung meningkatkan ketimpangan pendapatan dalam jangka pendek tetapi akan menguranginya dalam jangka panjang.

Soeharjoto (2020) dalam studinya menyimpulkan jika tingkat partisipasi angkatan kerja berpengaruh negatif dan signifikan terhadap ketimpangan pendapatan. Syahputra et. al. (2019) dalam studinya mendapatkan kesimpulan yang berbeda, dimana jumlah angkatan kerja mampu meningkatkan ketimpangan pendapatan. 


\section{Metode}

Data yang digunakan dalam penelitian ini adalah data sekunder pada periode waktu 2010-2019 (sebelum pandemi) serta pada tahun 2020 untuk data pada masa pandemi COVID19. Data Rasio Gini dan Tingkat Partisipasi Angkatan Kerja (TPAK) didapat dari Badan Pusat Statistik (BPS). Data Dana Alokasi Umum (DAU), Dana Alokasi Khusus (DAK), serta Dana Bagi Hasil (DBH) didapatkan dari Direktorat Jenderal Perimbangan Keuangan Kementerian Keuangan (DJPK Kemenkeu). Data mengenai foreign direct investment (FDI) didapatkan melalui Badan Koordinasi Penanaman Modal (BKPM) dan Badan Pusat Statistik (BPS).

Adapun metode analisis data yang digunakan pada penelitian ini adalah menggunakan analisis regresi data panel (panel data regression analysis). Berdasarkan analisis regresi data panel maka dibentuklah model sebagai berikut:

$$
Y=a+\beta_{1} X_{1} i t+\beta_{2} X_{2} i t+\beta_{3} X_{3} i t+\beta_{4} X_{4} i t+\beta_{5} X_{5} i t+e
$$

Penjelasan: Y merupakan variabel terikat yaitu ketimpangan pendapatan yang diukur menggunakan Rasio Gini; $\alpha$ merupakan konstanta; $\beta(1 . .3)$ merupakan koefisien masing masing variabel independen; X1 merupakan Dana Alokasi Umum (DAU); X2 merupakan Dana Alokasi Khusus (DAK); X3 merupakan Dana Bagi Hasil (DBH); X4 merupakan Foreign Direct Investment (FDI); X5 merupakan tenaga kerja yang diukur menggunakan Tingkat Partisipasi Angkatan Kerja (TPAK); dan e merupakan error term.

Sebelum melakukan analisis regresi data panel, hal yang perlu dilakukan adalah memilih pendekatan terbaik. Adapun pendekatan yang ada pada analisis regresi data panel adalah: Common Effect Model (CEM), Fixed Effect Model (FEM), dan Random Effect Model (REM). Untuk memilih model estimasi terbaik dilakukan tiga uji untuk menentukannya. Adapun ketiga uji adalah sebagai berikut: (1) Uji Chow; uji ini dilakukan untuk menentukan model Fixed Effect Model atau Common Effect Model yang paling tepat digunakan dalam mengestimasi data panel. Apabila nilai F hitung lebih kecil dari F kritis maka hipotesis nul diterima yang artinya model yang tepat adalah menggunakan Common Effect Model. (2) Uji Hausman; uji ini dilakukan untuk menentukan model Fixed Effect Model atau Random Effect Model yang paling tepat digunakan dalam mengestimasi data panel. Apabila nilai statistik Hausman lebih kecil dari nilai kritis ChiSquares maka artinya model yang tepat untuk digunakan adalah Random Effect Model. (3) Uji Lagrange Multiplier; uji ini dilakukan untuk menentukan model Common Effect Model atau Random Effect Model yang paling tepat digunakan dalam mengestimasi data panel. Apabila nilai LM hitung lebih besar dari nilai kritis Chi-Squares maka artinya model yang tepat adalah menggunakan Common Effect Model.

Metode estimasi model Random Effect Model menggunakan metode Generalized Least Square (GLS), sedangkan model Fixed Effect Model (FEM) dan Common Effect Model (CEM) menggunakan Ordinary Least Square (Gujarati \& Porter, 2009). Salah satu kelebihan metode GLS yaitu tidak perlu memenuhi asumsi klasik. Uji asumsi klasik pada metode Ordinary Least Square (OLS) terdiri dari 5, yaitu uji linieritas, normalitas, autokorelasi, multikolinieritas, serta heteroskedastisitas. Namun, pada regresi data panel tidak semua uji asumsi klasik yang ada pada metode OLS digunakan, hanya uji multikolinieritas dan heteroskedastisitas saja yang diperlukan (Basuki, 2016).

Uji hipotesis dilakukan untuk menentukan seberapa besar pengaruh variabel independen terhadap variabel terikat. Uji signifikansi parsial (Uji t) menunjukkan seberapa jauh variabel 
bebas secara individu dalam menjelaskan variabel terikat dengan menganggap variabel bebas lainnya adalah konstan. Sedangkan, uji signifikansi simultan (Uji F) menunjukkan seberapa jauh variabel bebas secara keseluruhan dalam menjelaskan variabel terikat.

Koefisien determinasi bertujuan untuk mengetahui seberapa besar kemampuan dari variabel-variabel bebas dalam menjelaskan variabel terikat. Bila nilai koefisien determinasi yang diberi simbol R2 mendekati angka 1, maka variabel independen makin mendekati hubungan dengan variabel dependen, sehingga dapat dikatakan bahwa pengaruh model tersebut dapat dibenarkan (Gujarati, 1995).

\section{Hasil dan Pembahasan}

\subsection{Uji Chow}

Uji Chow dilakukan untuk menentukan model estimasi yang terbaik antara Common Effect Model (CEM) atau Fixed Effect Model (FEM). Hasil dari perhitungan Uji Chow dapat dilihat pada tabel dibawah ini.

Tabel 1. Hasil Uji Chow

\begin{tabular}{llll}
\hline $\begin{array}{l}\text { Redundant Fixed Effects Tests } \\
\text { Equation: Untitled } \\
\text { Test cross-section fixed effects }\end{array}$ & & & \\
\hline Effects Test & Statistic & d.f. & Prob. \\
\hline Cross-section F & 35.406277 & $(30,274)$ & 0.0000 \\
Cross-section Chi-square & 491.178936 & 30 & 0.0000 \\
\hline
\end{tabular}

Sumber: Hasil Estimasi Menggunakan Eviews 10

Dari hasil Uji Chow diketahui bahwa nilai probalilitas sebesar 0.0000 yang mana lebih kecil dari alpha 0.05, sehingga model yang terpilih adalah Fixed Effect Model (FEM).

\subsection{Uji Hausmann}

Uji Hausman dilakukan untuk menentukan model estimasi yang terbaik antara Random Effect Model (REM) dan Fixed Effect Model (FEM). Hasil dari perhitungan Uji Hausman dapat dilihat pada tabel dibawah ini.

Tabel 2. Hasil Uji Panjang Lag

Correlated Random Effects - Hausman Test

Equation: Untitled

Test cross-section random effects

\begin{tabular}{llll}
\hline Test Summary & Chi-Sq. Statistic & Chi-Sq. d.f. & Prob. \\
\hline Cross-section random & 3.712665 & 5 & 0.5915 \\
\hline
\end{tabular}

Sumber: Hasil Estimasi Menggunakan Eviews 10

Dari hasil Uji Hausman diketahui bahwa nilai probabilitas sebesar 0.5915 yang mana lebih besar dari alpha 0.05 sehingga model yang terpilih adalah Random Effect Model. 


\subsection{Hasil Uji Statisik}

Tabel 3. Hasil Uji t

\begin{tabular}{lllll}
\hline Variable & Coefficient & Std. Error & t-Statistic & Prob. \\
\hline C & 0.259676 & 0.141986 & 1.828892 & 0.0684 \\
LN_DAU & 0.007728 & 0.004777 & 1.617643 & 0.1068 \\
LN_DAK & -0.005052 & 0.001065 & -4.744351 & 0.0000 \\
LN_DBH & 0.001048 & 0.002901 & 0.361244 & 0.7182 \\
LN_FDI & 0.001502 & 0.001192 & 1.259741 & 0.2087 \\
TPAK & -0.000708 & 0.000636 & -1.113070 & 0.2666 \\
\hline
\end{tabular}

Sumber: Hasil Estimasi Menggunakan Eviews 10

Pada variabel DAU (X1) diperoleh probabilitas > alpha 0.05. Nilai probabilitas yang didapat sebesar 0.1068 dan memiliki nilai koefisien positif. Dapat disimpulkan bahwa DAU tidak berpengaruh signifikan dan memiliki hubungan yang positif terhadap ketimpangan pendapatan. Pada variabel DAK (X2) diperoleh probabilitas < alpha 0.05 . Nilai probabilitas yang didapat sebesar 0.0000 dan memiliki nilai koefisien negatif. Dapat disimpulkan bahwa DAK berpengaruh signifikan dan memiliki hubungan yang negatif terhadap ketimpangan pendapatan. Pada variabel DBH (X3) diperoleh probabilitas > alpha 0.05. Nilai probabilitas yang didapat sebesar 0.7182 dan memiliki nilai koefisien positif. Dapat disimpulkan bahwa DBH tidak berpengaruh signifikan dan memiliki hubungan yang positif terhadap ketimpangan pendapatan. Pada variabel FDI (X4) diperoleh probabilitas > alpha 0.05. Nilai probabilitas yang didapat sebesar 0.2087 dan memiliki nilai koefisien positif. Dapat disimpulkan bahwa FDI tidak berpengaruh signifikan dan memiliki hubungan yang positif terhadap ketimpangan pendapatan. Pada variabel TPAK (X5) diperoleh probabilitas $>$ alpha 0.05 . Nilai probabilitas yang didapat sebesar 0.2666 dan memiliki nilai koefisien negatif. Dapat disimpulkan bahwa TPAK tidak berpengaruh signifikan dan memiliki hubungan yang negatif terhadap ketimpangan pendapatan.

\section{Tabel 4. Hasil Uji F}

$\begin{array}{ll}\text { F-statistic } & 7.588463 \\ \text { Prob(F-statistic) } & 0.000001\end{array}$

Sumber: Hasil Estimasi Menggunakan Eviews 10

Berdasarkan hasil uji F yang terdapat pada tabel dapat diketahui bahwa nilai probabilitas dari F-Statistik adalah 0.000001 maka dapat disimpulkan bahwa seluruh variabel independen yaitu DAU, DAK, DBH, FDI, dan TPAK secara bersama-sama berpengaruh signifikan terhadap ketimpangan pendapatan.

\subsection{Uji Koefisiensi Determinasi (R-Square)}

Tabel 5. Hasil Uji Koefisiensi Determinasi (R-Square)

\begin{tabular}{ll}
\hline R-squared & 0.110961 \\
Adjusted R-squared & 0.096339 \\
\hline
\end{tabular}

Sumber: Hasil Estimasi Menggunakan Eviews 10

Dari tabel diatas dapat diketahui bahwa R-square sebesar 0.110961 atau 11.09 persen. Sehingga dapat disimpulkan bahwa variabel DAU, DAK, DBH, FDI, dan TPAK pada model regresi 
dapat menjelaskan variabel ketimpangan pendapatan sebesar 11.09 persen sedangkan sisanya sebesar 88.91 persen dijelaskan oleh variabel lain diluar model.

Berdasarkan rumus perhitungan diatas sangat masuk akal bila Dana Alokasi Umum (DAU) berpengaruh positif terhadap ketimpangan pendapatan pada provinsi - provinsi di Indonesia. Hal ini dilihat dari perhitungannya yang menggunakan pendekatan celah fiskal. Selisih antara kebutuhan fiskal $(\mathrm{KbF})$ dan kapasitas fiskal $(\mathrm{KpF})$ digunakan untuk menghitung $\mathrm{CF}$ daerah. Kemudian, untuk mengetahui alokasi berdasar celah fiskal suatu daerah dihitung dengan mengalikan bobot CF daerah bersangkutan (CF daerah dibagi dengan total CF nasional) dengan alokasi DAU CF nasional. Hal ini berakibat pada setiap daerah yang mengalami kesulitan dalam hal keuangan daerah yang ditandai dengan besarnya kebutuhan fiskal yang tidak diimbangi dengan kapasitas fiskal yang memadai akan menerima DAU yang lebih besar. Adapun dari Alokasi Dasar (AD) dihitung berdasarkan realisasi gaji PNS dari tahun sebelumnya dan tunjangan yang melekat sesuai dengan peraturan yang berlaku. Berdasarkan rumus bisa dilihat jika pengalokasian Dana Alokasi Umum (DAU) lebih ditekankan pada penggunaan administratif serta gaji pegawai negeri sipil (PNS). Gaji pegawai negeri sipil ditempatkan pada komponen sendiri dalam perhitungan. Akibatnya, dana alokasi umum secara tidak langsung hanya dinikmati oleh sebagian orang yang mana menjabat atau bekerja pada tatanan pemerintahan. Sedangkan, tidak semua masyarakat yang tinggal disuatu daerah bekerja menjadi pegawai negeri sipil. Sehingga, hal ini memicu ketimpangan yang meningkat karena gaji PNS yang cenderung tetap atau bahkan meningkat di tiap tahunnya dan pendapatan yang diperoleh oleh masyarakat non PNS lebih fluktuatif dan menyebabkan alokasi Dana Alokasi Umum berpengaruh positif terhadap ketimpangan pendapatan. Refqi \& Hidayat (2019) menemukan hasil yang berbeda dalam penelitiannya. Mereka menyatakan bahwa DAU dapat mendorong pertumbuhan ekonomi dengan mempertahankan jumlah pejabat pemerintah yang terampil untuk membuat kebijakan yang efektif. Dengan semakin meningkatnya gaji pegawai, maka akan semakin meningkatkan kualitas serta integritas dari pegawai atau dalam hal ini pembuat kebijakan yang akan semakin memberikan kontribusi terbaik dalam hal kesejahteraan masyarakatnya.

Berdasarkan perhitungan regresi data panel yang sudah dilakukan didapatkan hasil bahwa Dana Alokasi Khusus berpengaruh negatif dan signifikan terhadap ketimpangan pendapatan di Indonesia. Hal tersebut bisa dibuktikan dengan kondisi teknis berkaitan dengan penyusunan alokasi Dana Alokasi Khusus yang dilakukan. Tidak seperti instrumen lain yang tidak memerlukan persyaratan khusus, untuk dapat menerima Dana Alokasi Khusus perlu adanya beberapa kriteria. Kriteria-kriteria ini tentu saja yang berkaitan dengan kondisi keuangan yang dibawah rata-rata serta kondisi daerah yang merupakan daerah otonomi khusus ataupun daerah tertinggal yang terletak di perbatasan, pesisir, ataupun daerah rawan lainnya. Sehingga, dengan penentuan tersebut menyebabkan dana lebih tepat sasaran. Dana akan diterima oleh daerah-daerah yang memang membutuhkan untuk proses pemerataan dengan perhitungan yang sesuai. Selain itu, dana yang diberikan tidak digunakan secara sembarangan atau sia-sia karena dana yang diberikan harus berdasarkan prioritas nasional dari pemerintah pusat. Dana harus digunakan pada bidang-bidang yang sudah dijelaskan diantaranya: pendidikan, kesehatan, infrastruktur (jalan, irigasi, air minum, sanitasi), prasarana pemerintahan desa, sarana dan prasarana kawasan perbatasan, kelautan dan perikanan, pertanian, keluarga berencana, kehutanan, sarana dan prasarana daerah tertinggal, sarana perdagangan, energi pedesaan, perumahan dan permukiman, dan bidang keselamatan transportasi. Bidang-bidang tersebut merupakan bidang yang sangat membantu dalam proses 
pemerataan serta menunjang kegiatan ekonomi daerah tersebut. Ditambah lagi, pelaksanaan DAK sendiri diarahkan pada kegiatan investasi pembangunan, pengadaan, peningkatan dan/atau perbaikan sarana prasarana fisik pelayanan masyarakat. Sebagai contoh bidang infrastruktur jalan yang dialokasikan untuk pembangunan serta perawatan jalan baik level provinsi maupun kabupaten/kota. Ketika akses jalan yang tersedia di suatu daerah sangat memadai serta baik maka akan membuka aksesibilitas ke daerah tersebut. Hal ini akan mendukung pengembangan koridor ekonomi wilayah/kawasan. Ketika akses jalan terbuka maka perekonomian di daerah tersebut menjadi ramai. Mulai muncul investor yang akan menanamkan modalnya di daerah tersebut karena potensial. Sehingga akan muncul industriindustri baru yang akan menyerap tenaga kerja di daerah tersebut. Akhirnya hal tersebut akan berpengaruh pada pengurangan angka pengangguran serta ketimpangan pendapatan masyarakat. Contoh lain ada pada bidang pendidikan. Alokasi pada bidang pendidikan digunakan untuk pembangunan sarana prasarana yang menunjang mutu pendidikan di daerah tersebut, seperti pembangunan perpustakaan serta fasilitas lainnya di sekolah tersebut. Hal ini secara tidak langsung akan berdampak pada peningkatan kualitas SDM yang dihasilkan atau yang tersedia di daerah tersebut. Sehingga, ketika SDM tersebut menjadi tenaga kerja akan lebih mudah terserap serta mendapatkan pekerjaan yang sesuai dengan kompetensi serta kemampuannya. Terserapnya angkatan kerja ke pasar tenaga kerja akan menurunkan angka pengangguran yang selanjutnya akan menurunkan angka ketimpangan pendapatan.

Berdasarkan rumus perhitungan diatas sangat masuk akal bila Dana Bagi Hasil (DBH) berpengaruh positif terhadap ketimpangan pendapatan pada provinsi - provinsi di Indonesia. Hal ini disebabkan oleh sistem pengalokasian DBH yang berdasarkan kontribusi dari tiap daerah kepada pusat. Proporsi yang lebih besar didapatkan oleh provinsi atau daerah yang memiliki sumber daya alam (SDA) yang melimpah dan pajak yang besar. Otomatis, daerah yang memiliki sumber daya yang besar, baik alam maupun dari pajak akan semakin kaya daripada daerah yang biasa - biasa saja atau bahkan tidak memiliki sumber daya alam sama sekali. Pada akhirnya, pembangunan di tiap daerah menjadi tidak merata dan mengakibatkan angka ketimpangan pendapatan menjadi meningkat. Sebagai contoh, daerah Papua Barat yang memiliki tambang PT. Freeport di wilayahnya mendapatkan DBH relatif lebih besar dari daerah lain di Indonesia. Provinsi Jawa Timur juga memiiki DBH yang relatif besar karena beberapa sumber daya alam yang dimiliki seperti tambang minyak di Kabupaten Bojonegoro serta hasil dari pajak yang cukup besar. Refqi \& Hidayat (2019) dalam penelitiannya mendapatkan hasil yang serupa. Dalam penelitiannya dijelaskan jika pengadaan Dana Bagi Hasil ini sedikit kontradiktif dengan upaya pemerintah dalam hal pemerataan kapasitas fiskal antar daerah.

Di Indonesia kondisi antar provinsi sangat beragam baik dari segi demografi maupun geografis wilayah. Tentu saja kondisi tiap wilayah yang berbeda menyebabkan kondisi perekonomian yang berbeda pula di tiap daerah. Perkembangan ekonomi yang baik serta prospek yang menjanjikan tentunya akan menarik para investor, khususnya investor asing untuk menanamkan modalnya di daerah tersebut. Berdasarkan data dari BPS, menunjukkan jika penyebaran investasi asing yang datang ke provinsi-provinsi di Indonesia masih belum merata. Investasi terbesar masih dipegang pada daerah-daerah di Pulau Jawa. Provinsi Jawa Barat menjadi provinsi dengan realisasi PMA tertinggi pada penelitian ini diikuti dengan wilayah lain seperti Banten dan Jawa Timur. Hal ini karena di wilayah-wilayah tersebut memiliki perkembangan ekonomi yang baik. Infrastruktur serta fasilitas penunjang lebih lengkap serta penduduk Indonesia masih berpusat di Pulau Jawa sehingga banyak sumber daya manusia yang tersedia. Hal ini yang menarik investor untuk menanamkan modalnya di sana. Sedangkan, di 
wilayah-wilayah lain di luar Pulau Jawa perkembangan investasi masih kurang karena kegiatan perekonomian yang lebih lambat dari Pulau Jawa. Semakin bagus prospek suatu daerah maka semakin banyak investor untuk masuk didalamnya.

Dari segi preferensi, investasi yang dilakukan di Indonesia, khususnya investasi asing mulai beralih kepada sektor tersier yang lebih padat modal ketimbang sektor primer dan sekunder yang lebih padat karya. Hal ini bisa dilihat pada data yang dirilis oleh BKPM yang menunjukkan pada dua tahun terakhir (2018-2019) sektor tersier menempati persentase teratas dalam kontribusi pada total realisasi investasi pada tahun tersebut. Hal ini tentu saja akan berpengaruh pada ketimpangan yang ada di Indonesia, dimana akan semakin memperparah kondisi tersebut. Ketika investasi akan lebih condong kepada proyek yang padat modal maka lapangan pekerjaan akan berkurang karena tidak terlalu banyak membutuhkan tenaga kerja baru, sehingga banyak tenaga kerja yang tidak terserap dan menimbulkan banyak pengangguran dan ketimpangan semakin meningkat. Hal ini yang juga menjelaskan pengaruh positif antara Foreign Direct Investment terhadap ketimpangan pendapatan pada penelitian ini.

Di Indonesia, kondisi tingkat partisipasi angkatan kerja mengalami fluktuasi. Pada tahun 2010 sampai tahun 2012 sempat mengalami naik turun. Kemudian, pada tahun selanjutnya, hingga tahun 2015 nilai TPAK anjlok hingga pada titik 65.76 persen. Mulai tahun 2016, angka TPAK naik hingga pada tahun 2018 mencapai 67.26 persen. Jika data dilihat dari tingkat provinsi semua mengalami fluktuasi. Tidak ada yang menunjukkan sebuah tren tertentu, dimana di tiap tahunnya mengalami peningkatan dan penurunan. Hal ini yang menjadi salah satu alasan mengapa tingkat partisipasi angkatan kerja (TPAK) tidak berpengaruh signifikan terhadap ketimpangan pendapatan di tiap-tiap provinsi di Indonesia. Tingkat Partisipasi Angkatan Kerja memiliki koefisien yang negatif terhadap ketimpangan pendapatan di Indonesia, yang artinya setiap TPAK meningkat maka akan berpotensi menurunkan tingkat ketimpangan pendapatan di Indonesia dengan asumsi variabel lain dianggap konstan. Hal ini didukung dengan meningkatnya TPAK di total seluruh provinsi di Indonesia (secara nasional) sejak tahun 2015. Dengan meningkatnya TPAK tentunya akan mempengaruhi pendapatan masyarakat dimana akan meningkat sehingga akan mengurangi ketimpangan di Indonesia. Disamping itu, penyerapan tenaga kerja di Indonesia menunjukkan hasil yang positif, dimana hal ini dibuktikan dengan data mengenai jumlah pengangguran pada total angkatan kerja di total seluruh provinsi di Indonesia yang mengalami tren menurun. Pada tahun 2010, sebanyak 7.14 persen merupakan pengangguran sedangkan sisanya adalah tenaga kerja yang sudah bekerja. Kemudian tahun berikutnya sempat mengalami fluktuasi hingga pada tahun 2018 mencapai 5.34 persen pengangguran sedangkan sisanya merupakan tenaga kerja yang sudah bekerja. Dengan meningkatnya penawaran tenaga kerja disertai dengan penyerapan tenaga kerja yang baik maka akan mampu mengurangi tingkat ketimpangan pendapatan di tiap daerah di Indonesia.

Pandemi COVID-19 yang melanda dunia tentunya juga melanda Indonesia. Dengan adanya pandemi ini menyebabkan kondisi perekonomian di Indonesia terganggu. Hal ini dikarenakan kondisi yang memaksa dilakukan kebijakan lockdown atau PSBB yang menurunkan mobilitas masyarakat. Roda perekonomian berhenti sehingga menyebabkan pertumbuhan ekonomi sampai negatif. Permasalahan ekonomi lain yang timbul akibat dari adanya pandemi COVID-19 ini adalah permasalahan ketimpangan pendapatan. Masyarakat yang terdampak langsung akan adanya kebijakan PSBB adalah masyarakat dengan pendapatan menengah kebawah yang tidak bisa melakukan aktivitas konsumsi karena pendapatan mereka yang menurun. Data mengenai ketimpangan pendapatan pada masa pandemi COVID-19 dapat dilihat pada grafik dibawah ini: 


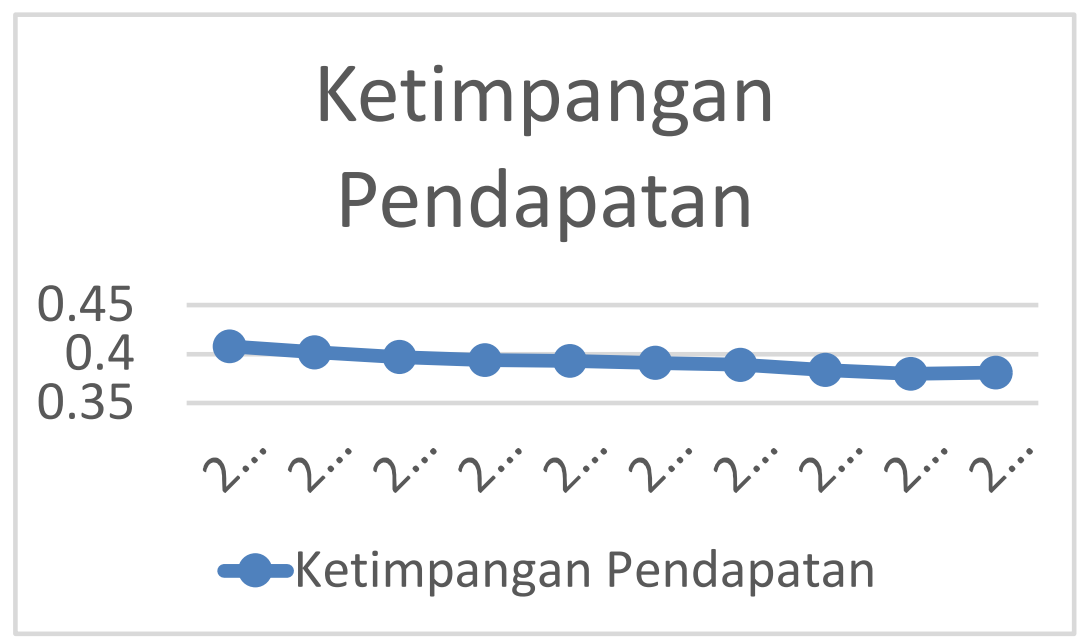

Gambar 1. Ketimpangan Pendapatan Pada Masa Pandemi COVID-19

Sumber: Badan Pusat Statistik (BPS)

Berdasarkan dapat dilihat jika sejak penurunan yang baik pada tahun 2015, pada saat pandemi COVID-19 jelas berdampak pada tingkat ketimpangan pendapatan yang ada di Indonesia secara keseluruhan. Pada tahun 2020 semester I terlihat jika tingkat ketimpangan pendapatan Indonesia meningkat dari 0.38 menjadi 0.381 . Kondisi ini tidak lepas dari adanya pengaruh kebijakan PSBB yang dilakukan oleh pemerintah dalam mengatasi pandemi COVID19. Masyarakat dengan pendapatan menengah kebawah sangat rentan terhadap kebijakan ini. Masyarakat kelas bawah banyak yang bekerja pada sektor informal yang membutuhkan kerja langsung ke lapangan. Dengan adanya kebijakan ini akan berdampak pada pekerjaan mereka. Banyak masyarakat yang tidak bisa melakukan aktivitas konsumsi karena pendapatan mereka yang turun. Di satu sisi, masyarakat dengan pendapatan menengah keatas tidak begitu berdampak dengan munculnya pandemi ini. Hal ini dikarenakan mereka memiliki tabungan yang lebih serta pendapatan yang lebih untuk bertahan selama masa pandemi, sehingga tidak akan mempengaruhi konsumsi dari masyarakat tersebut.

Pada masa pandemi COVID-19 tentunya perekonomian di setiap negara, termasuk Indonesia akan mengalami gangguan. Pemerintah selaku pembuat kebijakan perlu melakukan terobosan - terobosan terbaru terkait dengan penyesuaian dengan kondisi pandemi seperti saat ini. Dampak pandemi juga tidak hanya dirasakan secara kesehatan tetapi juga dari sisi ekonomi, khususnya dampak bagi pengalokasian dana perimbangan ke setiap daerah. Berikut ini adalah gambaran kondisi pengalokasian DAU, DAK, dan DBH sebelum pandemi dan pada saat pandemi COVID-19 berlangsung: 


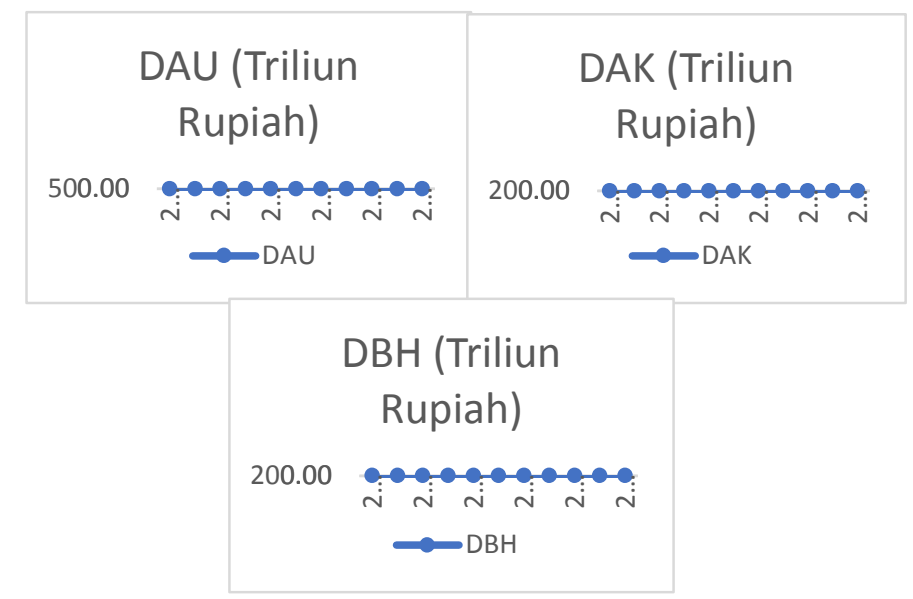

Sumber: Badan Pusat Statistik (BPS)

Berdasarkan ketiga grafik diatas dapat dilihat jika munculnya pandemi COVID-19 di Indonesia mempengaruhi kondisi desentralisasi fiskal di Indonesia. Baik DAU, DAK, maupun DBH mengalami penurunan pada tahun 2020 yang pada saat itu terjadi pandemi COVID-19 di Indonesia. Hal ini disebabkan salah satunya karena menurunnya penerimaan negara diakibatkan karena kondisi perekonomian negara yang sedang mengalami goncangan. Volume APBD turun signifikan, dimana belanja APBD secara nasional turun hingga 30 persen (setara 385 triliun). Sehingga, pemerintah pusat melakukan beberapa penyesuaian guna alokasi DAU, DAK, dan DBH dapat terkucurkan dengan maksimal berkaitan dengan penanganan pandemi COVID19. Adapun Dana Bagi Hasil dikurangi sebesar 21.1 persen mengikuti penerimaan negara. Pada alokasi DAU dilakukan pemotongan sebesar 10 persen. Adapun DAK dibagi menjadi DAK fisik dan non fisik. Pada DAK fisik, alokasi dana dipotong sebesar 25 persen dari pagu awal. Pemotongan dilakukan untuk bidang selain pendidikan dan kesehatan, karena kedua bidang ini yang paling terdampak akibat dari munculnya pandemi COVID-19. Sedangkan, untuk DAK non fisik dilakukan penambahan pada bidang kesehatan berupa Bantuan Operasional Kesehatan (BOK) sebesar 3.7 triliun rupiah untuk insentif tenaga medis.

Selain melakukan penyesuaian terhadap alokasi TKDD, pemerintah pusat melakukan refokusing terhadap TKDD tahun anggaran 2020 yang bertujuan untuk menangani pandemi COVID-19. Untuk Dana Bagi Hasil (DBH) dan Dana Alokasi Umum (DAU) dilakukan refokusing sebesar 4.6 triliun rupiah dan 4 triliun rupiah. DBH CHT, DBH SDA Migas dalam rangka Otsus dan belanja infrastruktur 25 persen DTU dapat digunakan sebagian atau seluruhnya untuk penanganan pandemi COVID-19. Selain itu, sisa DBH DR yang masih terdapat di RKUD dapat digunakan maksimal 25 persen untuk mendanai kegiatan dalam rangka menghadapi pandemi COVID-19. Kemudian, untuk Dana Alokasi Khusus (DAK) dibagi lagi menjadi DAK fisik dan non fisik. DAK fisik dilakukan refokusing sebesar 9.3 triliun rupiah dengan penggunaan difokuskan untuk pembangunan ruang isolasi, pengadaan ventilator, dan mobile x-ray. Sedangkan, untuk DAK non fisik dilakukan refokusing sebesar 7.2 triliun rupiah dengan penggunaan untuk bantuan puskesmas, balai faskes, dan insentif nakesda yang menangani COVID-19 (BOK tambahan). 
Investasi khususnya investasi asing merupakan salah satu faktor yang mempengaruhi perekonomian suatu negara. Di masa pandemi seperti saat ini sangat diperlukan kucuran modal, khususnya modal asing agar perekonomian di Indonesia dapat terus bertahan. Adapun gambaran mengenai perbandingan data terkait realisasi penanaman modal asing di Indonesia pada masa sebelum dan pada saat pandemi COVID-19 adalah sebagai berikut:

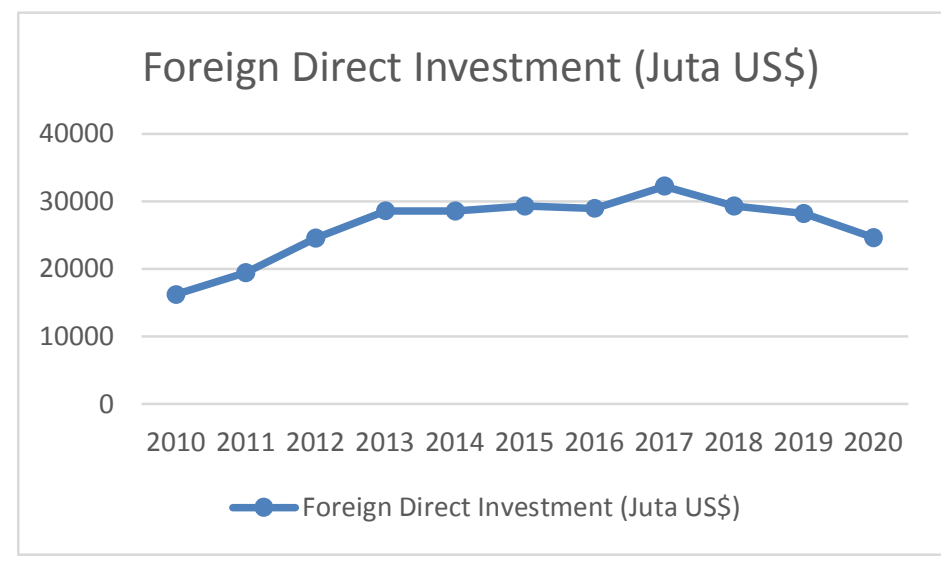

\section{Gambar 3. FDI Pada Masa Pandemi COVID-19}

Sumber: Badan Koordinasi Penanaman Modal (BKPM)

Berdasarkan data diatas tampak jika perkembangan FDI di Indonesia mengalami penurunan pada masa pandemi COVID-19. Data diawali hampir selama satu dekade pada tahun 2010 dimana nilai FDI Indonesia sebesar 16214.8 Juta US\$. Kemudian terus mengalami perkembangan hingga puncaknya pada tahun 2017 nilai FDI Indonesia adalah sebesar 32239.8 Juta US\$. Tahun - tahun berikutnya nilai dari FDI Indonesia mulai mengalami penurunan hingga pada saat terjadi pandemi COVID-19 pada tahun 2020 nilai FDI Indonesia mencapai 24606.5 Juta US\$. Hal ini artinya terjadi penurunan sekitar 12.77 persen dari tahun sebelumnya yaitu tahun 2019. Hal ini menunjukkan adanya kekhawatiran dari pihak investor untuk menanamkan modalnya ke Indonesia mengingat pandemi COVID-19 di Indonesia sampai saat ini masih berlangsung. Kondisi pandemi memunculkan kekhawatiran akan setiap usaha yang dilakukan akan berakhir rugi karena kebijakan PSBB sehingga menghambat proses berjalannya suatu industri di setiap sektor.

Berdasarkan data yang dirilis oleh BPS, perkembangan tenaga kerja Indonesia semakin baik, khususnya mulai tahun 2015, dimana tingkat partisipasi angkatan kerja Indonesia semakin meningkat. Hal ini menandakan jika penawaran tenaga kerja di Indonesia semakin meningkat. Bahkan, pada saat pandemi pun kondisi TPAK tetap mengalami peningkatan. Berbeda dengan tahun sebelumnya yang sempat mengalami fluktuasi dari tahun 2010 hingga tahun 2014. Tampak tidak ada dampak yang signifikan dengan munculnya pandemi COVID-19 terhadap kondisi tingkat partisipasi angkatan kerja di Indonesia. Namun, jika data dilihat secara detail lagi maka akan muncul pengaruh yang cukup signifikan. Tingkat partisipasi angkatan kerja sendiri merupakan persentase penduduk usia kerja yang aktif secara ekonomi di suatu negara. Adapun penduduk usia kerja dihitung menggunakan jumlah angkatan kerja yang didalamnya terdiri dari jumlah orang yang bekerja dan jumlah pengangguran. Untuk melihat data mengenai persentase penduduk bekerja dan tingkat pengangguran di Indonesia pada masa sebelum dan pada saat kemunculan pandemi COVID-19 dapat dilihat pada grafik dibawah ini: 


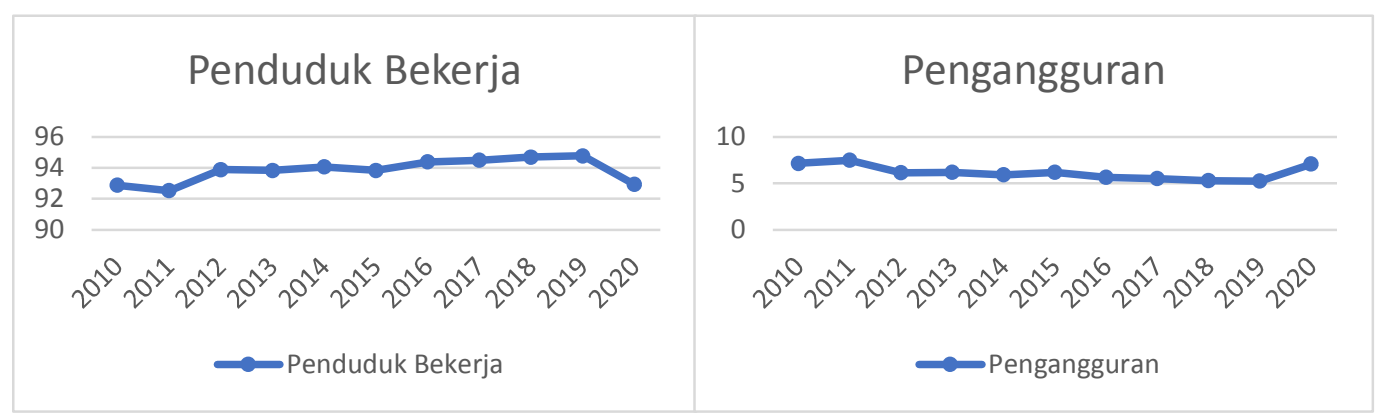

Gambar 4. Penduduk Bekerja dan Pengangguran Pada Masa COVID-19

Sumber: Badan Pusat Statistik (BPS)

Berdasarkan data diatas tampak jelas pengaruh pandemi COVID-19 terhadap kondisi ketenagakerjaan di Indonesia. Pada hampir 1 dekade terakhir tampak tren yang baik pada persentase jumlah orang yang bekerja maupun tingkat pengangguran. Persentase jumlah orang yang bekerja mengalami peningkatan secara konsisten mulai tahun 2015 hingga tahun 2019. Pada tahun 2015, jumlah orang yang bekerja mencapai 93.82 persen dari total angkatan kerja. Pada tahun 2019 meningkat menjadi 94.77 persen dari total angkatan kerja. Begitu juga sebaliknya, tingkat pengangguran di Indonesia mengalami tren menurun selama hampir 1 dekade terakhir. Tahun 2011 menjadi tingkat pengangguran paling tinggi sejak tahun 2010 yaitu sebesar 7.48 persen dari total angkatan kerja. Setelah tahun tersebut terus menurun hingga turun 2 persen lebih di tahun 2019 dengan nilai 5.23 persen dari total angkatan kerja. Pandemi COVID-19 mulai masuk di Indonesia pada awal tahun 2020 dan masih terus berlanjut. Ketika terjadi pandemi pemerintah melakukan kebijakan PSBB/lockdown yang tentunya berdampak bagi segala aspek salah satunya ekonomi. Kebijakan lockdown menyebabkan roda perekonomian terhambat, dimana pendapatan masyarakat kelas menengah kebawah menjadi berkurang sehingga menyebabkan konsumsi berkurang. Banyak industri yang kesulitan untuk berkembang karena mengalami kerugian karena produk yang dibuat tidak dapat dibeli oleh masyarakat. Hal ini berdampak pada pengurangan biaya oleh perusahaan yang salah satunya adalah dengan melakukan PHK bagi sebagian tenaga kerja yang dimiliki. Hal ini berdampak pada meningkatnya tingkat pengangguran di Indonesia pada masa pandemi COVID-19.

\section{Simpulan}

Berdasarkan hasil penelitian ini dapat disimpulkan jika Dana Alokasi Umum (DAU), Dana

Bagi Hasil (DBH), Foreign Direct Investment (FDI), dan tenaga kerja tidak berpengaruh signifikan terhadap ketimpangan pendapatan di Indonesia. Adapun hanya Dana Alokasi Khusus (DAK) saja yang berpengaruh signifikan terhadap ketimpangan pendapatan di Indonesia. Arah koefisien yang negatif menyebabkan penurunan angka ketimpangan pendapatan di provinsi di Indonesia ketika Dana Alokasi Khusus (DAK) meningkat, dengan asumsi variabel lain dianggap tetap. Dana Alokasi Khusus merupakan dana yang diserahkan kepada daerah dalam rangka program nasional. Metode perhitungan sangat menentukan penerima dana, khususnya bagi daerah yang sangat kurang dalam hal pembangunan. Adapun Dana Alokasi Umum (DAU) memiliki probabilitas yang hampir mendekati alpha 0.05 dan memiliki koefisien yang lebih besar dari Dana Alokasi Khusus (DAK). Artinya, DAU memiliki potensi untuk mempengaruhi angka ketimpangan di provinsi di Indonesia. 
Pada saat terjadi pandemi COVID-19, hampir semua variabel terdampak buruk bagi perekonomian, hanya tingkat partisipasi angkatan kerja saja yang tidak mengalami perubahan pada saat sebelum dan ketika dilanda pandemi COVID-19. Namun, ketika data dipecah menjadi jumlah orang bekerja dan jumlah pengangguran maka terlihat jelas dampak yang terjadi dimana angka pengangguran semakin meningkat. Adanya penurunan perekonomian di Indonesia ini disebabkan karena kebijakan PSBB / lockdown yang dilakukan oleh pemerintah sehingga menyebabkan turunnya mobilitas penduduk. Akibatnya, roda perekonomian menjadi terganggu dan pertumbuhan ekonomi menjadi terhambat.

Saran yang bisa dilakukan oleh pemangku kebijakan berkaitan dengan hasil penelitian ini adalah pemerintah bisa berfokus pada peningkatan Dana Alokasi Khusus (DAK) dalam memerangi ketimpangan pendapatan di Indonesia. Ketika Dana Alokasi Khusus meningkat, maka pembangunan yang terjadi di daerah-daerah semakin banyak yang menyebabkan fasilitas di tiap daerah bisa merata. Alhasil, pembangunan yang lebih merata akan menyebabkan pertumbuhan ekonomi di tiap daerah bisa lebih meningkat. Ketika pertumbuhan ekonomi meningkat disertai fasilitas yang memadai maka akan merangsang roda perekonomian, meningkatkan daya beli masyarakat yang akhirnya menurunkan tingkat ketimpangan pendapatan. Untuk penelitian selanjutnya, diharapkan bisa mengembangkan penelitian ini dengan menggunakan variabel lain yang berpotensi berpengaruh terhadap ketimpangan pendapatan.

\section{Daftar Rujukan}

Arsyad, L. (2016). Ekonomi Pembangunan Edisi Ke-5. Yogyakarta: UPP STIM YKPN

Badan Pusat Statistik. (2019). [Seri 2010] Produk Domestik Regional Bruto per Kapita (Ribu Rupiah), 2010-2019, diunduh dari https://www.bps.go.id/indicator/52/288/1/-seri-2010-produk-domestik-regionalbruto-per-kapita.html

Badan Pusat Statistik. (2019). Gini Rasio 2002-2020, diunduh dari https://www.bps.go.id/indicator/23/98/1/gini-rasio.html

Badan Pusast Statistik. (2019). Tingkat Partisipasi Angkatan Kerja (TPAK), diakses dari https://sirusa.bps.go.id/sirusa/index.php/indikator/51

Basuki, A. T., \& Prawoto, N. (2016). Analisis Regresi Dalam Penelitian Ekonomi \& Bisnis: Dilengkapi Aplikasi SPSS \& Eviews. Depok: PT. Rajagrafindo Persada.

Cho, H. C., \& Ramirez, M. D. (2016). Foreign Direct Investment and Income Inequality in Southeast Asia; a Panel Unit Root and Panel Cointegration Analysis, 1990-2013. Atlantic Economic Journal, 44(4), 411-424. doi: 10.1007/s11293-016-9521-7

Fazaalloh, A. M. (2019). Is Foreign Direct Investment Helpful to Reduce Income Inequality in Indonesia?. Economics and Sosiology, 12(3), 25-36. doi: 10.14254/2071-789X.2019/12-3/2

Gujarati, D. N. (1995). Dasar-Dasar Ilmu Ekonometrika. Jakarta: Penerbit Erlangga.

Gujarati, D. \& Porter, D. (2009). Dasar-dasar Ekonometrika (Terjemahan). Jakarta: Salemba Empat.

Khusaini, M. (2006). Ekonomi Publik: Desentralisasi Fiskal dan Pembangunan Daerah. Malang: BPFE UNIBRAW.

Krugman, P.R., \& Obstfeld, M. (1999). Ekonomi Internasional: Teori dan Kebijakan Edisi Kedua. Jakarta: PT. Rajagrafindo Persada.

Kuncoro, M. (2003). Ekonomi Pembangunan: Teori, Masalah, dan Kebijakan Edisi Ketiga. Yogyakarta: UPP AMP YKPN.

Lindaman, K., \& Thurmaier, K. (2002). Beyond Efficiency and Economy: An Examination of Basic Needs and Fiscal Decentralization. Economic Development and Cultural Change, 50(4), 915-934. doi: 10.1086/342760

Mankiw, G. (2006). Makroekonomi Edisi Keenam. Jakarta: Penerbit Erlangga.

Mankiw, G. (2018). Pengantar Ekonomi Makro Edisi 7. Jakarta: Salemba Empat. 
Mihaylova, S. (2015). Foreign Direct Investment and Income Inequality in Central and Eastern Europe. Theoretical and Applied Economics, 22(2), 23-42. Downloaded from https://econpapers.repec.org/article/agrjournl/v_3axxii_3ay_3a2015_3ai_3a2(603)_3ap_3a23-42.htm

Musgrave, R.A., \& Musgrave, P.B. (1984). Public Finance in Theory and Practice (4th edition). New York: McGrawHill

Oates, W.E. (1972). Fiscal Decentralization and Economic Development. National Tax Journal, 46(3), 237-243. Downloaded from https://www.ntanet.org/NTJ/46/2/ntj-v46n02p237-43-fiscal-decentralizationeconomic-development.pdf

Prawoto, N., \& Cahyani, R.D. (2020). Analysis of Unequal Distribution of Population Income in Indonesia. Journal of Asian Finance, Economics and Business, 7(7), 489-495. doi: 10.13106/jafeb.2020.vol7.no7.489

Putri, Y.E., \& Erita. (2019). Analisis Pertumbuhan Ekonomi dan Ketimpangan Pendapatan, Panel Data Enam Provinsi di Pulau Jawa. Jurnal Inovasi Pendidikan Ekonomi, 9(1), 27-38. doi: 10.24036/011041740

Refqi, M., \& Hidayat, A.K. (2019). Determinants of Regional Disparities in Indonesia: Lessons from Provincial Level. Working Papers in Economics and Development Studies (WoPEDS), Working Paper downloaded from http://ceds.feb.unpad.ac.id/wopeds/201906.pdf

Salvatore, D. (1997). Ekonomi Internasional Edisi Kelima. Jakarta: PT. Gelora Aksara Pratama.

Sidik, M., Hidayat, S., \& Ridwansyah, M. (2020). Dampak Alokasi Dana Perimbangan (DAU, DAK, DBH) Terhadap Tingkat Ketimpangan Antar Daerah di Provinsi Jambi Periode 2010-2019. Jurnal Paradigma Ekonomika, 15(2), 229-238. doi: 10.22437/paradigma.v15i2.10325

Soeharjoto. (2020). Factors That Affect Inequality Distribution Income in Cetral Java. International Journal of Economics, Business and Accounting Research (IJEBAR), 3(4), 122-130. Downloaded from https://jurnal.stie-aas.ac.id/index.php/IJEBAR/article/view/1196

Sukirno, S. (2006). Makroekonomi Teori Pengantar Edisi Ketiga. Jakarta: PT. Rajagrafindo Persada.

Suryahani, I., Susilowati, I., \& S.B.M., Nugroho. (2018). Impact of Economic Growth Per Capita and Foreign Direct Investment on Income Inequality in Indonesia. E3S Web Conference, 73(10031), 1-4. doi: 10/1051/e3sconf/20187310013

Syahputra, Y., Daulay, M., \& Ruslan, D. (2019). Analysis of Economic Development Inequality in Sumatera Utara Province. International Journal of Research and Review, 6(12), 331-340. doi: 10.52403/ijrr

Todaro, M.P., \& Smith, S.C. (2011). Pembangunan Ekonomi Edisi Kesebelas (Jilid 1). Jakarta: Penerbit Erlangga.

Nomor, U. U. R. I. (33). Tahun 2004 tentang Perimbangan Keuangan antara Pemerintah Pusat dan Pemerintah Daerah. Direktorat Jenderal Otonomi Daerah, Jakarta.

Undang-Undang Nomor 25 Tahun 2007 tentang Penanaman Modal, diunduh dari https://www.ojk.go.id 